\title{
Evaluation of National School for Professional Technhology

\author{
EDUCATION IN MEXICO
}

\author{
Gladys López-Acevedo* \\ [gacevedo@worldbank.org]
}

World Bank Policy Research Working Paper 3572, April 2005

The Policy Research Working Paper Series disseminates the findings of work in progress to encourage the exchange of ideas about development issues. An objective of the series is to get the findings out quickly, even if the presentations are less than fully polished. The papers carry the names of the authors and should be cited accordingly. The findings, interpretations, and conclusions expressed in this paper are entirely those of the authors. They do not necessarily represent the view of the World Bank, its Executive Directors, or the countries they represent. Policy Research Working Papers are available online at http://econ.worldbank.org.

\footnotetext{
* Senior Economist, LCSPP. This research was completed as part of the "Training Mechanisms Reform" project at the World Bank. I am grateful to Indermit S. Gill and Anna Maria Sant'anna, task managers of the project. Comments were received from the Council for Standardization and Certification of Labor Competencies (CONOCER) and from CONALEP. I am also grateful to the Paul Gertler, Jaime Saavedra, and Francisco G. Ferreira for their comments on the earlier version of this paper. Monica Tinajero and Marcela Rubio provided valuable research support.
} 


\begin{abstract}
National School for Professional Education Technology (CONALEP) is Mexico's largest and oldest technical education system. CONALEP serves lowincome students at the upper-secondary school level in Mexico. The labor market performance of CONALEP graduates has been evaluated four times in the past. These evaluations have yielded encouraging results, showing that CONALEP's graduates find jobs faster and earn higher wages than similar "control" groups. In contrast, using non-experimental methods, this paper suggests that CONALEP's graduates might earn higher wages but do not find jobs faster compared to control groups.
\end{abstract}

Keywords: impact evaluation and technical education 


\section{INTRODUCTION}

CONALEP (The National School for Technology) is the backbone of Mexico's skills training structure and is the most important government technology education system. CONALEP serves low-income students at the upper-secondary school level in Mexico. Several attempts have been made to evaluate the labor market performance of technology education graduates in Mexico. ${ }^{1}$ Past evaluations have found that CONALEP increases earnings by a magnitude of 30 to 40 percent. $^{2}$ However, these results must be viewed with caution since each previous evaluation encountered difficulty constructing control groups against which the CONALEP graduates could be compared. Using the non-experimental methods of double difference and propensity score matching, this paper re-evaluates the labor market performance of CONALEP graduates.

The paper is organized into seven sections. Section 1 provides an overview of the educational system in Mexico and the role of CONALEP within this system. Section 2 describes CONALEP's features, its rapid expansion, and the main characteristics of its student body. Section 3 reviews the data used in past evaluations as well as in the present evaluation. Section 4 describes the methodology and results of CONALEP's past evaluations. Section 5 discusses the methodology and results of the present analysis, and section 6 discusses cost-benefit analysis Finally, section 7 offers conclusions.

\footnotetext{
${ }^{1}$ See World Bank (1997) and Carnoy et. al., (2000).

${ }^{2}$ Past evaluations include CONALEP (1994), CONALEP (1999), Lane and Tan (1996), World Bank (1997), Kye (1998), and Carnoy and others (2000). These are further discussed in section three of this paper.
} 


\section{THE EdUCATIONAL SYSTEM AND CONALEP}

The structure of Mexico's educational system is separated into two main parts: 1) basic education 2) upper-secondary education. Basic education is the Mexican government's highest priority. The basic education system consists of: (A) mandatory childhood education (or preschool), for children 3 to 5 years old; (B) mandatory primary education, for children aged 6 to 12, or 6 to 14 due to late enrollment and grade, and (C) mandatory basic lower-secondary school education, consisting of a 3-year cycle, and intended for children aged 12 to 16.

Upper-secondary education in Mexico is non-mandatory. It consists of a 3-year cycle and is intended for teenagers 16 to 19 years old. This educational level is comprised of three tracks: (1) bachillerato general (general upper-secondary), (2) bachillerato bivalente (dual track uppersecondary/technological upper-secondary), and (3) profesional medio (middle professional/vocational education/ technical upper-secondary).

The Mexican upper-secondary educational system is similar in design to the French system. The main difference between the two is the existence of a "dual track" track at the upper-secondary level, which is a hybrid between vocational education and humanistic-scientific tracks. Mexico relies more on vocational education than any other Latin American country; almost 40 percent of lower secondary students are streamed into the vocational and dual track track schools (Boud and Garrick, 1999; Hobart, 1999). Since CONALEP was created as an alternative to the general upper-secondary education the following paragraphs discuss the current upper-secondary tracks in greater detail.

\section{General upper-secondary}

Two main bodies govern general upper-secondary schools. While the Ministry of Education (SEP) administers the majority of general upper-secondary schools, the autonomous 
universities such as Universidad Autónoma de Mexico (UNAM) and Instituto Politécnico Nacional (IPN) administer a smaller number of long-established schools. The public universities have historically regarded these schools as preparatory schools for university entry. General education is the preferred stream for students entering upper-secondary and has about 60 percent of students, a proportion that has remained more or less constant over the last 13 years (Table 1). In absolute terms the number of students has been growing by about 4 percent a year and is now in the order of 3.3 million (Table 1).

\section{Dual track/technological upper-secondary}

These institutions are also described as dual track schools, awarding occupation-specific technician qualifications as well as high school diplomas (bachillerato) necessary for access to tertiary education. Both SEP and state governments administer dual track/technical uppersecondary schools. State governments have shown a preference for opening dual track schools as opposed to general upper-secondary schools or middle professional. ${ }^{3}$ As a result, the proportion of students in dual track schools has increased from around 20.5 percent to almost 30 percent during the last thirteen years. The absolute number is almost one million students (Table 1), of which almost 90 percent are in state schools (Table 2). These schools offer a range of areas of study (Table 3).

\section{Middle Professional/vocational upper-secondary}

Most public schools in this track are administered through a decentralized system managed by CONALEP, affecting 63 percent of the total enrollment (Table 4). CONALEP was established in 1978 as a way of experimenting with alternative forms of technical and vocational

\footnotetext{
${ }^{3}$ The dual track upper secondary system has been less regulated by Federal SEP both in the opening and
} 
education. ${ }^{4}$ Originally, CONALEP schools provided no access to higher education, and were often referred to as terminal vocational schools. However, as of 2000 students may undertake additional electives that enable them to meet pre-requisites for tertiary education. Despite the option to enter tertiary education, it seems that the majority of students do not go on. ${ }^{5}$ The proportion of upper-secondary students in this track has decreased from 18 percent to almost 11 percent in the last 13 years. In absolute terms, the number of students has remained around 370,000 students (Table 4). Middle professional also offers a wide range of careers mainly focused on the manufacturing and services sectors (Table 5).

The complex arrangement of the upper-secondary level is outlined in Table 6. As can be seen, a variety of agencies and schools constitute the technical education and training system in Mexico. The following section describes the characteristics of CONALEP in greater detail.

\section{CONALEP}

In December of 1978, the Mexican Government created CONALEP as a public decentralized body of SEP. CONALEP was intended to provide a national network of uppersecondary schools that would prepare young people to become technicians at the uppersecondary educational level. With the establishment of CONALEP, the Mexican government wanted to establish a client-focused system of vocational education.

In 1979, the first ten CONALEP schools were opened, offering training in seven careers to 4,100 students. By 1982, there were 158 schools and 72,281 students. In 2000, there were 262 schools and 203,000 students. As shown in Table 7, the largest expansion of CONALEP was

\footnotetext{
operation of the schools, particularly since the education decentralization.

${ }^{4}$ In another paper (López-Acevedo, 2001), the benefits of the 1992-1994 CONALEP reforms are evaluated.

${ }^{5}$ The author's discussions on the proportion of students who take the additional subjects in the States of Puebla and Hidalgo (October 2001) elicited informal estimates of 90 percent and 75 percent respectively.
} 
from 1979 to 1986 from 9 to 239 schools and from 4,100 to 132,044 students. During this period, the annual enrollment rate was 4.5 percent.

By 1986, all 31 states in Mexico and Mexico City had CONALEP schools (Table 8). The distribution of students by state was, however, uneven, with the majority of students attending CONALEP schools in Mexico City and Edo. De Mexico. The sizes of CONALEP schools were also uneven.

CONALEP has the following two unique features that differentiate it from other uppersecondary schools: 1) since 1997 the technical career curriculum is based on competency-based education and training standards (CBET), and 2) since 1999 CONALEP sells its services to the industry to match federal funding.

CBET is part of the Programa para la Modernización de la Educación Técnica y la Capacitación (PMETyC), which is the most comprehensive effort to introduce vocational qualification standards into the technical education and training systems in Mexico. CBET brings the employers and the schools together and provides outcomes against which the success of a particular course may be assessed, hence increasing accountability of the system. CONALEP's curriculum is divided into two parts. The first part of the program takes up 65 percent of the hours allocated over the three-year period and comprises of subject relevant to the students choice of technical career. The second part provides general curricula such as history and social sciences; communications; mathematics and general science; computing, and English. Completion of the general curricula qualifies students for tertiary education. CONALEP schools are financed both publicly and privately. On average, a CONALEP school receives up to 70 percent of its funding from Federal resources in the form of transfers for teacher salaries and the 
cost of infrastructure acquisitions. Teacher salaries are financed through the Fondo de Aportaciones para la Educación Tecnológica y de Adultos (FAETA), while infrastructure acquisitions through the Fondo de Aportaciones Múltiples (FAM). The remaining 30 percent of funding is raised by each school through tuition and the sale of services, such as job training courses, to industry. Most student tuition fees fall in the \$US90 to \$US130 a year range. The combination of these funds is used to cover operational expenses.

The absence of financing from state governments is unique to CONALEP schools. Since 1999 state governments have had to at least match the allocation of the federal government for all upper-secondary dual track and middle professional institutions; that is, states have had to contribute at least 50 percent of the expenditure for salaries and operations. CONALEP does not receive state funding because it was the first upper-secondary decentralized institution. Otherwise, CONALEP would have had equal cost sharing from federal and state governments.

Although CONALEP students' socioeconomic and academic levels do vary, they are generally characterized by low average entrance exam scores and low socioeconomic backgrounds. Data from the National Evaluation Center (Centro Nacional de Evaluación, CENEVAL $^{6}$ ) suggests that in Mexico City and Edo. De Mexico, CONALEP most frequently serves students from a lower socioeconomic status at the upper-secondary level. The results of a random sample of those who took the CENEVAL entrance examination to upper-secondary school in Mexico City and Edo. De Mexico in 1999 suggest that CONALEP students come from families with the lowest average income and the lowest parental education (Table 8). The

\footnotetext{
${ }^{6}$ The Centro Nacional de Evaluación para la Educación Superior A. C. (CENEVAL), created by the National Association of Universities and Higher Education Institutions (ANUIES) administers an annual entrance examination. This examination includes sections for verbal ability (30 points), mathematical ability (30 points) and general knowledge of physics, chemistry, biology, geography and history for a total of 128 points. The examination is designed so that the student results are distributed along a normal curve with the mean score being 64 points. A minimum of 31 points is required to enter any school, including CONALEP, and those applicants to CONALEP
} 
parents of an average CONALEP student have about two years less formal education than the parents of a student attending a general upper-secondary school such as Colegio de Bachilleres, and three years less formal education than the parents of students attending the high schools of the IPN.

However, students attending CONALEP do not necessarily do poorly on the entrance test, nor do they all come from low educated parents. About 20 percent of CONALEP students in this sample scored higher than the average student attending the Colegio de Bachilleres. Approximately 35 to 40 percent of the parents of CONALEP students have higher levels of education than the parents of an average student at the Colegio de Bachilleres. This implies that the families of CONALEP students comprise an unequal distribution. Though a significant portion of students score higher and have parents with more education than students of Colegio Bachilleres, the average indicators of CONALEP students are weighed down by low-income students with low scores in the CENEVAL examination. Only students attending other dual track and middle professional schools (CETIS and CBTIS) within the Dirección General de Educación Tecnológica (DGETI) system are comparable to CONALEP students in respect to these indicators.

However, there are signs that the academic entrance level of CONALEP students is increasing. Carnoy et al. (2000) found that CONALEP student entry test scores have consistently increased since 1997. They also found that somewhat less than half of CONALEP students in their third and final year indicated that CONALEP was their first choice of the uppersecondary school tracks while almost more than half of the first year cohort say it was their first

who obtain between 31 and 45 points are required to take remedial courses. 
choice. This observation might imply that the quality of CONALEP is improving and that students are perceiving CONALEP as a good system.

\section{DATA}

The previous four evaluations of the labor market performance of CONALEP graduates relied mainly on the CONALEP graduate tracer surveys. In addition, the present paper relies on the National Employment Survey (ENE 98) and the National Employment, Schooling and Training Survey (ENECE 99). The main characteristics of these surveys are summarized in the following paragraphs.

\section{The CONALEP Graduate tracer Survey}

CONALEP has been evaluated by information gathered through CONALEP graduate tracer surveys (1994, 1998, 1999 and 20037), which are unfortunately comprised of mostly qualitative questions.

The first CONALEP graduate tracer survey was conducted in February 1994 (CONALEP, 1994) on a random sample of 1,500 former CONALEP students who graduated between June 1991 and June 1993. The surveyed graduates were selected to represent the profile of the graduates in each of the three years in terms of all 13 major occupational careers and the six geographical regions of the country. However, the sample was dominated by 1992 graduates who comprised 50 percent while 1991 and 1993 graduates, each represented 25 percent (Tables 9 and 10). The sample selection was probabilistic and statistically representative of the universe of graduates in each cohort. For each graduate $(\mathrm{M})$, three substitutes were chosen from the same career and school (S, T and Z). 
The second CONALEP graduate tracer survey (CONALEP 1998) was conducted between May and June of 1998 on a random sample of individuals who graduated between June 1993 and June 1997. The sample is representative of the six geographical regions of the country, all 29 careers, and all cohorts. Table 11 shows the distribution of the 1998 CONALEP survey. This table shows that the response rate is high with the exception of the 90-93 cohort. Table 12 shows that the difference between the actual sample of 5,580 individuals and the planned sample of 9,463 was due to factors such as changes in address (above 33\%); did not find the address (21.1 percent); and addresses that belonged to different states (0.1 percent), all of which decrease by graduation cohort. Though Migration in Mexico is high and is usually related to age, gender, and education, migration did not cause bias in the sample. Tables 13 and 14 do not show systematic differences in gender and age between respondents and non-respondents.

\section{The ENE 98 and ENECE 99 Surveys}

Two surveys are used in the present paper, the ENE 98 and the ENECE 99. Both surveys are representative at the national and regional level. These surveys have rich information on individual labor market characteristics. The ENE 98 has a sample size of nearly 200,000 individuals. The ENECE 99 is a module of the national employment survey (ENE 99). The 1999 sample size was 164,550 individuals. The ENECE has additional useful information on the professional profile of the individuals and the type of training received (in-firm, external training, etc.), training time, date of training, and place of training.

\footnotetext{
${ }^{7}$ The information coming from the survey was released last month.
} 


\section{CONALEP's Past evaluations}

CONALEP has been evaluated four times since the early 1990s, with the main objective of qualitatively assessing the market labor performance of CONALEP graduates. Two evaluations were done by CONALEP (1994) and CONALEP (1999). The other two evaluations were done by Lane and Tan $(1996)^{8}$ and by Kye (1998). These four evaluations used the CONALEP graduate tracer surveys discussed in the previous section. A separate evaluation was performed by international consultants (Carnoy et al, 2000) hired by CONALEP with the objective of assessing the evolution of the CONALEP system. For this purpose the consultants used a different data set as explained below.

The main objective of each CONALEP evaluation was to assess the qualitative labor market profile of CONALEP graduates. However, the CONALEP evaluations had several problems, one of the most important being the lack of well-defined control groups. Initiallty, control groups were expected to be added later, using data from the National Urban Employment Survey (ENEU). However, the final studies neither included in-depth information on how the analysis was performed nor did they provide useful information on how CONALEP graduates performed relative to control groups.

Lane and Tan (1996) also encountered several problems in their evaluation when attempting to construct a non-arbitrary "control" group using the ENEU 95 survey. This difficulty stems mainly from the fact that the ENEU sample is representative of metropolitan areas while the CONALEP graduate tracer survey, used for the treatment group, is representative of the nation and of the six geographical regions of the country. The difference in geographical coverage of the two groups made the comparison difficult. Second, the control groups were 
constructed ad hoc. The control groups included individuals between the ages of 17 and 30 with the following characteristics: (A) those who have completed lower-secondary education; (B) those who have completed non-professional, elementary vocational training (CECATI), and (C) those who have completed one to three years of general academic (non-vocational) high school. Some doubts remain with respect to the second group, since the ENEU survey does not distinguish between formal and informal training/technical courses.

Kye (1998) compared individuals from the CONALEP graduate tracer survey (1994), with two other control groups selected from the 1991 graduates of upper-secondary diversified technical education programs. Each group's labor force participation and employment performance in January 1994 was compared to that of CONALEP graduates from 1991, and 1991-93 combined. The first comparison group was created from a mail survey of all graduates, with a 45 percent response rate, and therefore is likely to be biased toward those who were either employed, studying, or had a higher level of earnings. The second comparison group was made up of employed workers aged 20 to 24, as reported in the aggregates of the ENEU 94.

The results of these evaluations concluded that CONALEP graduates actively participate in the labor market at a much higher rate than the similar age cohort of the general population, and at a much higher rate than graduates from traditional technical high schools. On average, CONALEP graduates found jobs faster than control individuals, and about two-thirds of CONALEP graduates worked in jobs related to the specialization they had studied. Using crosscohort comparison, these evaluations also suggested that CONALEP graduates' earnings increased rapidly within the first two to three years of employment.

\footnotetext{
${ }^{8}$ This is the same evaluation used in the World Bank (1997) report.
} 
Though these results were for the most part expected, the magnitudes of the participation rate and the increase in earnings in comparison to the general population and to technological, and technical high schools were surprisingly high. Earnings increased 30 percent according to Lane and Tan, and 40 percent according to Lee. However, the results should be considered cautiously because the studies failed to control for self-selection bias that could have led to an overestimate of labor market outcomes for CONALEP graduates. In addition, though the evaluations note the populations from which the control groups were selected, they do not adequately explain how the control groups were constructed.

The evaluation performed by Carnoy et. al. (2000) aimed at understanding the evolution of CONALEP with regards to the academic and socioeconomic level of its incoming students. The evaluation collected data through a survey administered to 5 percent of the senior and freshmen classes, the treatment and control groups respectively. The sample consisted of 4,930 seniors and 725 freshmen. Based on their responses, the groups were further disaggregated into three groups using a socioeconomic status indicator.

The results are for the most part consistent with those from CENEVAL discussed in Section 2. They note that close to one-third of the students from CONALEP come from a low socioeconomic background. Another 40 percent come from a middle socioeconomic range. About 18 percent have parents who have completed basic secondary school or more, own a home with four or more rooms and have a car, a phone, or both.

The average entry test scores for the sample show several important trends in social class, gender, and cohort. Girls in both cohorts enter CONALEP with slightly lower scores than boys. The first year (1999) cohort entered with higher scores than the third year (1997) cohort, which suggests that CONALEP student entry test scores have actually risen more than suggested by the 
data. In the third-year cohort, entry scores were positively correlated with socioeconomic indicators for both boys and girls. However, there seems to be little relationship between socioeconomic status and entry score in the 1999 cohort, except for higher-class girls. Carnoy et al. (2000) concluded that CONALEP students tend to come from relatively low socioeconomic backgrounds and tend to score at the lower passing end of the upper-secondary school entry test. About half have general basic secondary education, with another third coming from basic technical secondary schools. Somewhat less than half of the third year students indicate that the CONALEP option was their first choice of higher secondary school, and roughly more than half of the first year cohort says it was their first choice.

During the same evaluation, a second questionnaire was given to firms that hired CONALEP graduates from regular courses or training courses. In general, the firms that hire students from CONALEP as well as those that use its training services think highly of the organization. Approximately 72 percent of firms think that the academic level attained by CONALEP students is high or very high. About 55 to 60 percent of companies said that the technological level of a CONALEP education is high or very high, with large public companies giving the lowest ranking (46 percent).

\section{Methodology ANd Results}

An evaluation that aims to understand the causal impact of a program must compare the performance of two groups: the treatment group and the control group. The former consists of the units (individual tracks, households, firms, etc) that participate in the program. The latter consists of units that do not participate in the program. The ideal evaluation requires the use of experimental methods, which implies that the above groups (treatment and non-treatment) would have been constructed by randomly assigning each unit to either group. With large samples 
randomization ensures that the two groups are mostly identical with the exception of the treatment. However, in evaluations of social science random selection is difficult. On many occasions the programs are focused or individuals have expectations of the programs, which affect their decisions to participate. This can give rise to an estimation bias. To limit such a bias the following non-experimental methods can be utilized: propensity score matching, reflexive comparisons, double difference, and instrumental variables ${ }^{9}$. In these methods individuals are not assigned randomly to control groups but are nevertheless similar to the treatment group in the most relevant characteristics. Heckman et al. (1997) outline the sources of bias as follows: ${ }^{10}$

a) For all participants there is not a comparable non-participant and vice versa.

b) There are different distributions of observable characteristics within the groups.

c) The selection bias created by unobservables; the differences in the resulting variable that remain despite controlling for the observable variables.

However, a) can be resolved by selecting a common region of support, while b) is eliminated with the methodology of matching. In respect to the bias created by unobservables, the double difference methodology has the advantage of removing any time-invariant differences. Furthermore Heckman et al. (1997) found that bias due to unobservables is less important than sources of bias a) and b). Empirically, Heckman found that when the same survey is applied to both groups and both groups are from a common economic environment, the performance of the estimators due to matching is more accurate. Neither method is perfect, yet one can match the advantages and disadvantages of each with the information provided and the objective of the given study. In this paper, two non-experimental methods are applied in an attempt to obtain a robust estimation of CONALEP's impact. The CONALEP evaluation presented next, unlike previous CONALEP evaluations, uses the non-experimental methods of

\footnotetext{
${ }^{9}$ Galiani, Gertler and Schargrodsky (2003) and Ravallion (1999).
} 
double differences and propensity score matching to control for the estimation bias discussed above. For the first technique, this paper follows closely Duflo (2000). Duflo evaluated the effect of one of the largest school construction programs on education and wages in Indonesia by combining differences across regions in the number of schools constructed with differences across cohorts induced by the timing of the program record. In principle, CONALEP is very close in design to the Indonesian school construction program evaluated by Duflo. However, there are two important differences. First, the Indonesian schools were constructed within a short time period (between 1973-74 and 1978-79 the number of existing schools was doubled), while the expansion of CONALEP was gradual. It took almost five years of expansion for the enrollment to approximately reach half of the present enrollment. Second, the information regarding the number of schools constructed during the period of major expansion was gathered by district in the Indonesian case and federal for CONALEP. ${ }^{11}$

\section{Difference in Differences}

This paper evaluates the labor market performance of graduates of CONALEP using the fact that exposure to CONALEP varied by region and age. The region and year of birth jointly determine an individuals exposure to the CONALEP's program, and only the combination of the two variations is treated as exogenous ${ }^{12}$. Using the ENECE99 ${ }^{13}$, the following age cohorts were constructed $^{14}$ :

(1) 24 to 29 years old in 1979

\footnotetext{
${ }^{10}$ It is important to mention that the method of matching reduces bias but does not eliminate it completely.

${ }^{11}$ Information at the municipal level was only available for 15 municipalities during the 1993-1994 period.

${ }^{12}$ Double difference, which compares the difference between the treatment and control groups, with the difference before and after the program has the advantage of removing differences due to unobsevables that do not vary with time.

${ }^{13}$ The analysis was also performed using the ENE98 and showed similar results as with the ENECE99, results with ENE98 are available upon request.

${ }^{14}$ The analysis only includes individuals in the non-general upper-secondary track.
} 
(2) 18 to 23 years old in 1979

(3) 4 to 9 years old in 1979

CONALEP was launched in 1979 and its major expansion was from 1979 to 1986 when all 31 states in Mexico had CONALEP schools. In this period, 230 more CONALEP schools were opened and 132,044 students were enrolled in CONALEP. Thus, an individual aged 24 in 1979 (cohort 1) did not benefit from CONALEP. An individual aged 18 years old in 1979 (cohort 2) normally did not benefit from CONALEP, since he/she should have left uppersecondary (at age 18) when CONALEP started in 1979. Grade repetition and delayed school entry could lead a few of these individuals to enroll in CONALEP. However, CONALEP's size in its first two years of operation was very small with only 4,100 students. Therefore, it is highly unlikely that cohort 2 would have benefited from CONALEP. Similarly, although the individuals in the group aged 10 to 17 in 1979 did have a chance to enroll in CONALEP; their exposure was ambiguous because the program was in its early process of expansion. Based on this ambiguity, the group is not included in the analysis. ${ }^{15}$ Finally, cohort (3) was fully exposed to CONALEP. In summary, individuals 18 and older in 1979 are highly unlikely to have been exposed to the program and while the youngest individuals in 1979 have the highest probability of exposure. As a result, the effect of the programs should be 0 for individuals 18 or older in 1979 and increasing for younger individuals.

Exposure to CONALEP also differs by region. In 1998-99, the share of enrollment in CONALEP to enrollment in technological upper-secondary schools varies across states (Figure 1). Two types of regions were constructed based on the enrollment of CONALEP relative to other technological upper secondary schools. In the region of high CONALEP presence,

\footnotetext{
${ }^{15}$ If the maximum age of cohort 3 was increased it would run the risk of extenuating the effects of the program
} 
CONALEP enrollment represents between 18.8 and 36.2 percent of the technological uppersecondary enrollment; in the region of low presence, CONALEP represents between 6.9 and 16.5 percent of the total technological upper-secondary enrollment. The basic idea behind the CONALEP identification strategy and the implications of its assumptions are illustrated using simple two-by-two tables. Table 15 shows the hourly earnings and share of people searching for a job and compares individuals who had no exposure to the program to those individuals who were always exposed in both regions with respect to these indicators. For both cohorts the average earnings per hour are higher in the region of high CONALEP presence. In both regions the hourly earnings increase with the age of the worker (maybe because of work experience), independent of the percentage of CONALEP present. Thus, the difference-in-difference estimation is not significant at a 90 percent confidence level. As a result, there is no significant evidence that the program increases the earnings of workers. It is important to mention that the difference-in-difference analysis between regions and cohorts (the casual effect of the program) assumes that, in the absence of the program, the increase in hourly earnings would not have been systematically different in low and high program regions.

With respect to the percent of individuals seeking employment, for both cohorts, there is no difference between regions of high and low CONALEP presence. In regions of low CONALEP presence, the youngest cohort seeks employment in greater proportion than the oldest cohort. In regions of high CONALEP presence, there is no difference between cohorts. Similar to the analysis of wages, the difference-in-differences is not significantly different from 0. Hence, the program has no significant effect on the percentage of persons seeking employment. An interesting aspect of this methodology is that the identification assumption can

given that the probability of no being in CONALEP increases uniformly with age. 
be tested. As observed in table 15, the difference between cohorts 1 and 2, between those who were and were not exposed to the treatment, does not vary systematically between regions. The difference-in-differences estimation for each variable is not significantly different from 0.

Nevertheless, the results are imprecise due to the assumption that there are no omitted time-varying and region specific effects correlated with the program. Characteristics that vary with either time or region and affect the program should be included in the estimation. In accordance with Duflo (2000), earnings were considered to depend on the state, the relative presence of CONALEP, the age cohort and a few other co-variables (at the state level). This relationship is outlined in the following equation:

$$
y_{i j k}=c+\alpha_{j}+\beta_{k}+\left(\mathrm{CONA}_{j} * \mathrm{COHO}_{k}\right) \cdot \gamma+\left(C_{j} * \mathrm{COHO}_{k}\right) \cdot \delta+\varepsilon_{i j k}
$$

where:

$$
\begin{aligned}
& y_{i j k} \quad \text { is the variable of interest, in this case the log of earning for individual i in } \\
& \text { state } \mathrm{j} \text { and cohort } \mathrm{k} \text {. } \\
& \alpha_{j} \quad \text { is the fixed effect of state. } \\
& \beta_{k} \quad \text { is the fixed effect of cohort. } \\
& \mathrm{CONA}_{j} \quad \text { tenotes the proportion of enrollment in CONALEP in respect to other } \\
& \mathrm{COHO}_{k} \quad \text { corresponds to the cohort of the individual. } \\
& \mathrm{C}_{j} \quad \text { is a vector of co-variables in state } \mathrm{j} .
\end{aligned}
$$

Variables included in ${ }^{C_{j}}$ were the following: the log of gross domestic product (GDP), percent of GDP in industry, the percent age of GDP in services, percent age of household with 
in-house piped water, the percent age of households with or connected to a drainage network or septic tank and, the log of enrollment in upper secondary education level.

Based on the advantages of double differences discussed earlier, that there is no omitted time-varying and region specific effects correlated with the program, $\gamma$ is the impact of CONALEP ${ }^{16}$.

The results are presented in table 16. The effect of CONALEP on the percentage of individuals seeking employment and the hourly earnings were not statistically different from 0 . Hence, CONALEP has no effect on these variables. However, it is important to mention that the effect of CONALEP equalling zero could be due to the low presence of the institution at the state level, in many cases lower than 15 percent. Therefore, the weight of the effect of CONALEP is small compared with the weight of the other technological upper-secondary schools. Another possible explanation of the results is that the regionalization is based on the relative presence of CONALEP in the state. Disaggregation at a smaller level, perhaps by municipality would have been preferable ${ }^{17}$. Smaller regions are advantageous because they might be more homogenous within their borders, and more heterogeneous across borders, than larger regions.

For instance, suppose that the mean of the variable of interest is $\bar{y}$ for the cohort not exposed to the program, and $\bar{y}^{\bar{y}}$ for the cohort exposed to the program for control region and $2 \bar{y}$ for the treatment region (high presence of CONALEP). While this may signify a positive effect of CONALEP on the variable of interest, the doubling effect of CONALEP on the variable of

\footnotetext{
${ }^{16}$ If the average of the variable of interest is obtained by cohort ( 4 to 9 and 18 to 23 years old) and relative presence of program (low and high intensity) using (1), then the effect of the program (the double difference) will be represented by $\gamma$.

${ }^{17}$ Unfortunately, information is not provided regarding neither the presence of CONALEP nor the co-variables at this level.
} 
interest is reduced to a 12 percent increase if CONALEP represents 25 percent of enrollment in high presence regions and only 13 percent in low presence regions.

Though the double difference method is optimal, as it eliminates the selection bias, , a second best option in the case of CONALEP is to apply matching which only controls for observable variables. The application of this method to the CONALEP case is explained below.

\section{Propensity Score Matching}

The difference-in-differences approach introduced above suggested that CONALEP did not have an impact on increasing earnings or reducing job search. However, as discussed earlier this approach had some limitations when applied to the CONALEP case given the available information. In the absence of better information to undertake a double difference approach, propensity score matching is used next. This paper does not intend to solve all the problems of selection bias in CONALEP by using propensity score matching ${ }^{18}$, but it represents an improvement with respect to previous evaluations of CONALEP.

As discussed by Todd (1999), the idea behind matching is to find a comparison group that is as similar as possible to the treatment group in terms of the relevant observable characteristics such as age, gender, education, location $^{19}$, as summarized by the propensity score. In calculating the propensity scores, we followed Todd's methodology (1999) and Gill and Dar (1995).

First, we chose two representative sample surveys of eligible non-participants as well as one of the participants. The two surveys of eligible non-participants are the ENE 98 and the

\footnotetext{
${ }^{18}$ As mentioned earlier, Heckman empirically found that the performance of matching estimator is better if the same survey is applied to the groups within the same economic environment. Although in this paper, the surveys (CONALEP, ENECE and ENE) are no the same, the questions used for matching are the same, and in order to control for common "economic" environment one of the variables included in the matching is location.

${ }^{19}$ Unfortunately, all the CONALEP graduate tracer survey contains mainly qualitative variables and very few
} 
ENECE $99^{20}$. Both surveys have the advantage of a large number of eligible non-participant respondents, which ensures good matching. The participant survey used is the CONALEP 98 graduate tracer survey. Although the participant and non-participant data come from different surveys, the surveys are comparable since some of the questions are identical, all are from similar survey periods, and all are nationally and regional representative. Given the objectives of the study, only those working or searching for a job and those who have at least completed lower secondary ${ }^{21}$ were considered in the matching exercise. Therefore the conclusion only refers to that population.

Next, the two samples were pooled and a logic model of CONALEP participation as a function of the variables that are likely to determine participation was estimated. The variables included were age, gender, education ${ }^{22}$, region of residence, and the location where in-firm training was undertaken. Although this exercise does not include important socioeconomic variables such as parent's schooling and household income, these two variables are captured in the education variable. As discussed in section 2, those students going into CONALEP, technical, and technological schools come from the lowest socioeconomic background in terms of parent's schooling, family income, and low GPA. Therefore, students in technical and technological education are similar in terms of socioeconomic characteristics but very different from those attending general upper-secondary such as UNAM or IPN (Table 6). The predicted values of the probability of participation, the propensity scores, were created from the logic

identical questions to the ENE or ENECE.

${ }^{20}$ This paper presents only the results using the ENECE 99, which are the same using the ENE 98. The ENE 98 results are available upon request.

${ }^{21}$ Only those who have completed lower-secondary school or more were included in the analysis because this is the requisite to enter CONALEP.

${ }^{22}$ Unfortunately, in the ENE and ENECE it is not possible to distinguish between technological, vocational education and the institution that the individual attended. Therefore, there is some probability of including a CONALEP graduate in the control group. However, CONALEP represent less than 7 percent of the total upper- 
regression for every sampled participant and non-participant. The model classified correctly 98 percent of the non-participant group cases and 88 percent of the participant group cases; the overall percentage of correctly predicted cases is 97 percent. Table 17 shows the percentage of correctly predicted cases when a given variable is excluded from the original model. When education is excluded, the model only predicts correctly 20 percent of the CONALEP cases.

Table 18 shows that individuals in the CONALEP and control groups are very similar. With the exception of state of residence, there is no statistically significant difference between the characteristics of the individuals in the CONALEP and those in the control group. According to table 18 , close to 77 percent of the individuals have complete upper-secondary technical education, close to 15 percent have complete technical University, close to 7 percent have university incomplete, and only close to 2 percent have university incomplete. It also reveals other socio-demographic characteristics. There are more males (close to 53 percent) than females (47 percent). With regards to age, 24 years is the average. With respect to training, close to 62 percent did not receive training, one quarter received in-firm training and 13 percent received external training.

Then, propensity scores of the three nearest neighbors are calculated. This means that for each individual in the CONALEP group, the three observations in the non-participant sample that have the closest propensity score were found, as measured by the absolute differences in scores. Alternatively, another transformation was used, the log-odds ratio $\log [p /(1-p)]$, where $p$ is the propensity score for matching. Heckman and others (1998) have proposed an alternative method for the nearest neighbor. Instead of relying on the nearest neighbor, they use all the nonparticipants as potential matches but weight each according to its proximity.

secondary enrollment. 
The mean values of the outcome indicators for the three nearest neighbors were computed using earnings, labor market status, economic sector, and training. The difference between the mean and the actual value for the treated observation is the estimate of the gain due to the program for that observation. The mean of these individual gains was computed to obtain the average overall gain.

On average, CONALEP graduates earned 22 percent more than the ENECE 99 control group (table 19), and 17 percent more than the ENE 98. Both differences are significant at 90 and 95 percent confidence levels. Controlling for hours worked, CONALEP graduates earn close to 27.5 percent more than the ENECE99 control group and 20 percent more than the ENE 98 control group. On both ENECE 99 and ENE 98, the 1994-1997 cohort's results are not statistically significant.

The labor force participation rate of CONALEP graduates is shown in Table 20. Contrary to previous studies, the results indicate that the share of CONALEP graduates in the working population is significantly lower than the control group. Moreover, the CONALEP job search share is not significantly higher compared to the control group. It appears, then, that the lack of employment of CONALEP graduates relative to the control group does not translate into a lack of income.

In general, there are no statistically significant differences between the employment status of CONALEP graduates compared to the control groups using either ENE 98 or ENECE 99 (table 21). A large proportion of both CONALEP graduates and the control group individuals are employees. The proportion of CONALEP self-employed is not higher than the ENE98 or ENECE99 control groups. There is also no clear pattern of this proportion through time. 
The highest percent of CONALEP graduates are employed in the sectors of commerce, restaurants and hotels, personnel and communications, and government (Table 22). Unsurprisingly, these sectors also employ the largest share of individuals in the control groups. A significantly higher proportion of CONALEP graduates work in manufacturing compared to the control group. In Mexico, both manufacturing and services employ close to 80 percent of the labor force. Few CONALEP graduates work in the primary sector, the extraction (mining) sector or the electricity and gas sectors. With respect to overall patterns of employment, considering both sector and labor market status, the results for the CONALEP group are almost identical to those obtained for the control groups, manufacturing being the exception.

Due to the ENE 98 and ENECE 99 limitations, it is not possible to assess in detail the type of job obtained by the individual. However, the CONALEP graduate tracer survey allows us to infer whether there is congruency in the CONALEP graduate professional profile. Among the employed CONALEP graduates, more than half reported that they were working in the occupational category congruent with their field of specialization. Close to 70 percent of employed graduates consistently reported that CONALEP training or specialization was "very useful" or "useful" in their current occupation. This high rate of congruency is comparable to the high rate among apprentices in Germany, but it is significantly higher than in other developed countries (Organisation for Economic Co-operation and Development, OECD 1997).

On average, either using the ENE98 or ENECE99, there are no significant differences in the rate of in-firm training between CONALEP and the control group (Table 23). However, a significant proportion of CONALEP graduates (89.7 percent) report that their training was related to their current employment or work activity. 


\section{Cost-Benefit AnAlysis}

Campos (2001) and Carnoy and others (2000) provide a very detailed discussion on the unit costs of CONALEP, the general bachillerato, the technical bachillerato other than CONALEP, and the media superior schools. Campos (2001) was commissioned by the World Bank. Unit cost data are provided for 1992, 1994, 1995, and 1998. Cost items are divided into two classes: investment in infrastructure and equipment, and operational expenses. Operational expenses include, among other things, salaries of teachers and administrators, security services, and utilities (electricity, telephone, and water). The cost data refer to the three-year program. The control group's unit cost per year is $\$ 11,512.90$, or 7.4 percent higher than CONALEP's unit cost of $\$ 10,719.98$ (in 1998 pesos). Following the matching exercise, the control group's average earnings are lower than CONALEP's average earnings $(\$ 26,504.40$ vs. $\$ 22,684.8,1998$

pesos). It follows that CONALEP's present value is always positive. An alternative scenario was estimated assuming the control group's unit cost was unknown, a discount rate of 5 percent, and that earnings differences remain constant over the next 30 years. The breakeven year, when the discounted present value of accumulated benefits equals costs, is 12 years in the alternative scenario. If opportunity costs are added, the breakeven year is 18 years. Assuming the analysis of this paper is accurate, that CONALEP has a positive effect on earnings, the results of Campos (2001) show that CONALEP can achieve greater impact at a lower cost than the program's alternatives.

\section{Conclusions}

The Mexican government introduced CONALEP as an alternative technology education system to traditional upper-secondary education. Using experimental methods, this paper re- 
examines the labor market performance of CONALEP's graduates. The evaluation results are inconclusive with respect to the impact of the program on earnings. The double difference results suggest that CONALEP did not increase earnings while the matching exercise suggests the opposite. In agreement with previous evaluations, the matching exercise suggests that CONALEP increases graduates' earnings. However, the order of magnitude of earnings increase differs greatly from previous studies. This paper finds that on average CONALEP increases graduates' earnings by $22 \%$ — not the 30 or $40 \%$ found in other studies - compared to a control group.

This paper also shows that CONALEP graduates do not search longer for a job compared to the control group. It also shows that CONALEP graduates do not receive more training than those in the control group.

It is difficult to discern the relative contribution of the different factors responsible for the potential good performance of CONALEP compared to the rest of the technology education systems (dual track and vocational systems), but it is safe to conclude that the special features of CONALEP have made it possible. These features include: a flexible curriculum (technical and general skills), its unique financing structure, and its strong link to industry. 


\section{REFERENCES}

Boud, D., and J. Garrick. 1999. Understanding Learning at Work. London: Routledge.

Campos, M. 2000. Estudio de Costos del CONALEP. Background paper for the Training Mechanisms Reform Project. Processed.

Carnoy, Martin, Gregor Ramsey, and Greg Woodburne. 2000. Aprendiendo a trabajar: Una revisión del Colegio Nacional de Educación Profesional Técnica y del Sistema de Universidades Tecnológicas de México. Secretaria de Educación Publica. Processed.

CONALEP (Colegio Nacional de Educación Profesional Técnica). 1994. Encuesta de Empleo a Egresados del CONALEP, Cohorts 1991, 1992, and 1993. Final Report.

- 1999. Encuesta de Empleo a Egresados del CONALEP, Cohorts 1991, 1992, 1993, 1994 and 1995. Final Report.

Duflo, Esther. 2000. "Schooling and Labor Market Consequences of School Construction in Indonesia: Evidence from an Unusual Policy Experiment." MIT, Department of Economics.

Galiani, Sebastian, Paul Gertler and Ernesto Shargrodski. 2003. "Water for Life: The Impact of Water Supply Privatization on Child Mortality" Under Review at the Journal of Political Economy

Gill, Indermit, and Amit Dar. 1995. "Costs and Effectiveness of Retraining in Hungary.” Internal Discussion Paper, Europe and Central Asia Region. The World Bank.

Heckman, James, et al. 1997. "Matching as an Econometric Evaluation Estimator: Evidence from Evaluating a Job Training Programme." Review of Economic Studies 64(4). October.

Heckman, James, et al. 1998. "Matching as an Econometric Evaluation Estimator." Review of Economic Studies 65(2). April.

Hobart, B. 1999. "Globalization and its Impact on VET." Review of Research. Adelaide. NCVER.

Kye, L. 1998. "An Alternative Technical Education System: A Case Study of Mexico." Working Paper No. 554. The World Bank.

Lane, J., and H. Tan. 1996. Evaluación del Programa DGETI. Processed.

Lee, K. W. 1998. "An Alternative Technical Education System: A Case of Study of Mexico.” International Journal of Educational Development. Oxford. 
López-Acevedo, G. 2000. "Teachers' Salaries and Professional Profile." HD Working Paper No.64. The World Bank.

López-Acevedo, G. 2001. "An Alternative Technical Education System: A Reassessment of CONALEP ”, World Bank Policy Research Paper, No. 2731.

Maloney, W., and G. López-Acevedo. 2000. A Comprehensive Development Agenda for Mexico: Note on Labor Markets in Mexico.

OECD (Organisation for Economic Co-operation and Development). 1997. Reviews of National Policies for Education: Mexico Higher Education. Paris.

- 2000. Education at a Glance. Paris.

Power, C. 1999. "Technical and Vocational Education for the Twenty-First Century." Prospects: Quarterly Review of Comparative Education. Vol. XXIX. No. 1. pp. 29-36. Paris. UNESCO.

Ravallion, M. 1999. "The Mystery of the Vanishing Benefits: Ms Speedy Analyst's Introduction to Evaluation." Handbook on Evaluating the Poverty Impact of Projects. The World Bank.

SEP (Secretaría de Educación Pública). Informe de Labores varios volumenes.

. 1998. Informe de Labores.

—.1999a. Informe de Labores.

—. 1999b. Compendio Estadistico por Entidad Federativa.

Smith, P. 1999. "The Internationalization of Vocational Education and Training." Review of Research. Adelaide. NCVER.

Todd, P. 1999. A Practical Guide to Implementing Matching Estimators. Processed.

World Bank. 1997. "Mexico: Training Assessment Study." World Bank, Washington D.C. Processed. 


\section{A Reassessment of the College of Professional Technical Education}

Table 1. Trends in Upper Secondary Education by Educational Track

\begin{tabular}{|c|c|c|c|c|}
\hline & 1990-1991 & 1995-1996 & 2000-2001 & $2002-2003$ \\
\hline \multicolumn{5}{|c|}{ Distribution of Enrollments } \\
\hline General & 61.5 & 57.8 & 59.6 & 60.0 \\
\hline Bivalent & 20.5 & 26.3 & 28.1 & 29.1 \\
\hline Technical/Vocational & 18.0 & 15.9 & 12.2 & 10.9 \\
\hline \multicolumn{5}{|l|}{ Number of students } \\
\hline$\overline{\text { General }}$ & $1,291,664$ & $1,409,948$ & $1,762,933$ & $1,977,450$ \\
\hline Bivalent & 429,962 & 640,741 & 831,309 & 958,651 \\
\hline Technical/Vocational & 378,894 & 387,987 & 361,541 & 359,171 \\
\hline Total & $2,100,520$ & $2,438,676$ & $2,955,783$ & $3,295,272$ \\
\hline
\end{tabular}

Source: Estadística Histórica del Sistema Educativo Nacional, SEP.

Table 2. Bivalent Upper Secondary by Managing Authority, 2002-2203

\begin{tabular}{lcc}
\hline & \multicolumn{2}{c}{ Students } \\
\cline { 2 - 3 } Managing Authority & Number & Proportion \\
\hline Government sector & 725,033 & 75.6 \\
\hline Industrial (DGTI?) & 107,133 & 11.2 \\
Agricultural (DGTA?) & 20,456 & 2.1 \\
Fishing & 3,188 & 0.3 \\
Forestry (CBTF?) & 855,810 & 89.3 \\
Total public sector & & \\
\hline Non-government sector & 102,841 & 10.7 \\
\hline Private & $\mathbf{9 5 8 , 6 5 1}$ & $\mathbf{1 0 0}$ \\
\hline Total
\end{tabular}

Source: Estadística Histórica del Sistema Educativo Nacional, SEP.

Table 3. Studies Offered by Bivalente System

Physics and mathematics

Agriculture and livestock

Construction

Electricity, electronics, control-telecommunications

Maintenance

Mining

Metal products

Textiles

Ecology and environmental improvement

Administration

Design

Tourism services
Aquiculture and fisheries

Computer and data processing

Design

Industrial

Internal combustion engines

Naval

Industrial safety

Chemical biological

Health

Commerce

Computer science

Social work

Source: National System for Technological Education, SEP 1998. 
Table 4. Middle Professional Upper Secondary by Managing Authority, 2002-2003

\begin{tabular}{lrc}
\hline & \multicolumn{2}{c}{ Students } \\
\cline { 2 - 3 } Managing Authority & Number & Proportion \\
\hline Government sector & \\
\hline CONALEP & 226,186 & 63.0 \\
IPN? & 23,848 & 6.6 \\
Other & 36,820 & 10.3 \\
Total public sector & 286,854 & 79.9 \\
\hline Non-government sector & & \\
\hline Private & 72,317 & 20.1 \\
\hline Total & $\mathbf{3 5 9 , 1 7 1}$ & $\mathbf{1 0 0}$ \\
\hline
\end{tabular}

Source: Estadística Histórica del Sistema Educativo Nacional, SEP.

Table 5. Studies Offered by Middle Professional High Schools

\begin{tabular}{ll}
\hline Physics and mathematics & Graphic arts \\
Automotive & Computing and data processing \\
Construction & Design \\
Electricity, electronics, and control telecommunications & Industrial \\
Maintenance & Internal combustion engines \\
Production and transformation processes & Metal products and metallurgy \\
Non-metal products & Chemical biology \\
Ecology and improvement of the environment & Health \\
Community services & Administration and accounting \\
Sea disciplines & Drawing and design \\
Tourism services & Social work \\
\hline
\end{tabular}

Source: National System for Technological Education, SEP 1998.

Table 6. Institutions/schools that provide Upper Secondary Education in Mexico General upper secondary Bivalent/Technological upper secondary Middle Professional upper secondary

\begin{tabular}{|c|c|c|}
\hline Bachiller Colleges (CB) & $\begin{array}{l}\text { Centers for Technical Industrial Studies } \\
\text { (CETI) }{ }^{2}\end{array}$ & $\begin{array}{l}\text { College of Professional Technical } \\
\text { Education (CONALEP) }\end{array}$ \\
\hline Preparatoria Schools & $\begin{array}{l}\text { Centers for Industrial and Services } \\
\text { Technological Studies (CETIS) }{ }^{7}\end{array}$ & 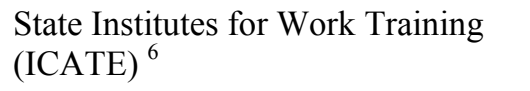 \\
\hline $\begin{array}{l}\text { Science and Humanities } \\
\text { Colleges }(\mathrm{CCH})\end{array}$ & $\begin{array}{l}\text { Centers for Industrial and Services } \\
\text { Technological Bachillerato (CBTIS) }\end{array}$ & $\begin{array}{l}\text { State Colleges for Scientific and } \\
\text { Technology Studies (CECyTE) }\end{array}$ \\
\hline \multirow[t]{3}{*}{ Incorporated Bachillerato ${ }^{1}$} & $\begin{array}{l}\text { Centers for Scientific and Technological } \\
\text { Studies (CECyT) } \\
\\
\text { Centers for Technological Studies (CET) }\end{array}$ & $\begin{array}{l}\text { Centers for Industrial and } \\
\text { Technological Services Studies } \\
\text { (CETIS) }{ }^{7} \\
\text { Centers for Industrial and Services } \\
\text { Technological Bachillerato (CBTIS) }\end{array}$ \\
\hline & $\begin{array}{l}\text { State Colleges for Scientific and } \\
\text { Technological Studies (CECyTE) }{ }^{6}\end{array}$ & $\begin{array}{l}\text { Nursing and Obstetrics School } \\
\left(\text { ESEO) }{ }^{8}\right.\end{array}$ \\
\hline & $\begin{array}{l}\text { Centers for Ocean Technological Studies } \\
\text { (CETMar) }{ }^{4}\end{array}$ & \\
\hline
\end{tabular}


Centers for Continental Water Studies

(CETAC) $^{4}$

Centers for Farming and Agricultural

Technological Bachillerato (CBTA) ${ }^{5}$

Centers for Forestry Technological

Bachillerato (CBTF) ${ }^{5}$

1. Incorporated to a state or federal university.

2. CETI offers technology programs.

3. CECyT and CET are coordinated by Instituto Politécnico Nacional (IPN).

4. CETMar and CETAC are coordinated by the Department of Scientific Education and Ocean Technology (UECyTM).

5. CBTA and CBTF are coordinated by the General Direction of Farming and Agricultural Education (DGTA).

6. ICATEs and CECyTEs are operated by the state governments.

7. CETIS and CBTIS are coordinated by the General Direction of Technological Industrial Education (DGETI).

8. ESEO is part of the IPN. It is the only modality in which graduates are professional technicians.

Source: SEP

Table 7. CONALEP Students and Schools

\begin{tabular}{lccccccc}
\hline & $\mathbf{1 9 7 9}$ & $\mathbf{1 9 8 2}$ & $\mathbf{1 9 8 6}$ & $\mathbf{1 9 9 0}$ & $\mathbf{2 0 0 0}$ & $\mathbf{2 0 0 1}$ & $\mathbf{2 0 0 2}$ \\
\hline Students & 4,100 & 72,281 & 132,044 & 155,329 & 193,313 & 193,948 & 181,063 \\
Schools & 9 & 158 & 239 & 248 & 262 & 264 & 268 \\
\hline
\end{tabular}

Source: CONALEP.

Table 8. CONALEP Schools by State and Year

\begin{tabular}{lccccccc}
\hline State & $\mathbf{1 9 7 9}$ & $\mathbf{1 9 8 2}$ & $\mathbf{1 9 8 6}$ & $\mathbf{1 9 9 0}$ & $\mathbf{2 0 0 0}$ & $\mathbf{2 0 0 1}$ & $\mathbf{2 0 0 2}$ \\
\hline Aguascalientes & 0 & 2 & 2 & 3 & 3 & 3 & 5 \\
Baja California & 0 & 5 & 6 & 6 & 6 & 6 & 6 \\
Baja California Sur & 0 & 1 & 1 & 1 & 2 & 2 & 2 \\
Campeche & 0 & 2 & 2 & 2 & 3 & 3 & 3 \\
Coahuila & 1 & 5 & 7 & 7 & 8 & 8 & 8 \\
Colima & 0 & 1 & 2 & 2 & 2 & 2 & 2 \\
Chiapas & 0 & 5 & 7 & 7 & 8 & 8 & 8 \\
Chihuahua & 0 & 3 & 7 & 7 & 7 & 7 & 7 \\
D. F. & 3 & 10 & 27 & 27 & 27 & 27 & 27 \\
Durango & 0 & 2 & 2 & 2 & 2 & 2 & 2 \\
Guanajuato & 0 & 5 & 10 & 11 & 12 & 12 & 12 \\
Guerrero & 0 & 7 & 8 & 8 & 8 & 8 & 8 \\
Hidalgo & 0 & 1 & 3 & 4 & 4 & 4 & 5 \\
Jalisco & 0 & 9 & 13 & 13 & 15 & 16 & 16 \\
Edo. de México & 3 & 18 & 38 & 39 & 39 & 39 & 39 \\
Michoacán & 0 & 8 & 12 & 12 & 13 & 13 & 13 \\
Morelos & 0 & 1 & 3 & 3 & 3 & 4 & 4 \\
Nayarit & 0 & 0 & 1 & 1 & 2 & 2 & 2
\end{tabular}




\begin{tabular}{lccccccc} 
Nuevo León & 0 & 6 & 8 & 9 & 9 & 9 & 9 \\
Oaxaca & 0 & 5 & 6 & 6 & 6 & 6 & 6 \\
Puebla & 0 & 7 & 8 & 8 & 10 & 10 & 10 \\
Querétaro & 0 & 2 & 2 & 2 & 3 & 3 & 3 \\
Quintana Roo & 2 & 4 & 4 & 4 & 4 & 4 & 5 \\
San Luis Potosí & 0 & 3 & 5 & 5 & 5 & 5 & 5 \\
Sinaloa & 0 & 12 & 12 & 12 & 12 & 12 & 12 \\
Sonora & 0 & 10 & 12 & 13 & 14 & 14 & 14 \\
Tabasco & 0 & 6 & 6 & 6 & 6 & 6 & 6 \\
Tamaulipas & 0 & 4 & 6 & 7 & 8 & 8 & 8 \\
Tlaxcala & 0 & 2 & 2 & 3 & 3 & 3 & 3 \\
Veracruz & 0 & 7 & 11 & 12 & 12 & 12 & 12 \\
Yucatán & 0 & 3 & 4 & 4 & 4 & 4 & 4 \\
Zacatecas & 0 & 2 & 2 & 2 & 2 & 2 & 2 \\
\hline Total & $\mathbf{9}$ & $\mathbf{1 5 8}$ & $\mathbf{2 3 9}$ & $\mathbf{2 4 8}$ & $\mathbf{2 6 2}$ & $\mathbf{2 6 4}$ & $\mathbf{2 6 8}$ \\
\hline Source: CONALEP
\end{tabular}

Source: CONALEP.

Table 9. CONALEP Students Compared to Students from Selected Institutions Centro Nacional de Evaluación

\begin{tabular}{|c|c|c|c|c|c|c|c|}
\hline $\begin{array}{c}\text { All } \\
\text { Institutions }\end{array}$ & $\begin{array}{l}\text { Option }^{1} \\
\text { Number }\end{array}$ & $\begin{array}{c}\text { Global }^{2} \\
\text { Test Score }\end{array}$ & $\begin{array}{l}\text { Family }^{3} \\
\text { Income }\end{array}$ & $\begin{array}{c}\text { GPA in }{ }^{4} \\
\text { Lower- } \\
\text { secondary }\end{array}$ & $\begin{array}{c}\text { Mother's } \\
\text { Schooling }^{5} \\
\text { (years) }\end{array}$ & $\begin{array}{c}\text { Father's } \\
\text { Schooling }^{5} \\
\text { (years) }\end{array}$ & $\begin{array}{c}\text { Private } \\
\text { Lower Sec }= \\
1\end{array}$ \\
\hline \multicolumn{8}{|l|}{ CONALEP } \\
\hline Mean & 2.27 & 54.2 & 2271.2 & 7.627 & 7.1 & 8.2 & 0.0087 \\
\hline $\mathrm{N}$ & 460 & 460 & 460 & 460 & 460 & 460 & 460 \\
\hline SD & 2.13 & 15.3 & 2269 & 0.6992 & 4.8 & 5.2 & 0.0929 \\
\hline \multicolumn{8}{|l|}{$\begin{array}{l}\text { Colegio de } \\
\text { Bachilleres }\end{array}$} \\
\hline Mean & 3.05 & 66.4 & 3132 & 7.658 & 9 & 10 & 0.0333 \\
\hline $\mathrm{N}$ & 421 & 421 & 421 & 421 & 421 & 421 & 421 \\
\hline SD & 2.28 & 13.2 & 2845 & 0.75722 & 5.2 & 5.1 & 0.1800 \\
\hline \multicolumn{8}{|l|}{ Estado de México } \\
\hline Mean & 2.41 & 64.6 & 2721 & 7.931 & 8.452 & 9.9 & 0.0176 \\
\hline $\mathrm{N}$ & 1192 & 1192 & 1192 & 1192 & 1192 & 1192 & 1192 \\
\hline SD & 2.09 & 16.56 & 2436 & 0.76 & 4.9 & 5.2 & 0.1300 \\
\hline \multicolumn{8}{|l|}{ DGETI } \\
\hline Mean & 2.71 & 59.6 & 2610 & 7.7205 & 7.7 & 9.2 & 0.0220 \\
\hline $\mathrm{N}$ & 682 & 682 & 682 & 682 & 682 & 682 & 682 \\
\hline SD & 2.32 & 15.6 & 2488 & 0.7271 & 5 & 5.4 & 0.1500 \\
\hline \multicolumn{8}{|l|}{ IPN } \\
\hline Mean & 1.97 & 80.7 & 3315 & 8.1865 & 9.8 & 11.3 & 0.0581 \\
\hline $\mathrm{N}$ & 430 & 430 & 430 & 430 & 430 & 430 & 430 \\
\hline SD & 1.61 & 13.9 & 2552 & 0.7871 & 4.7 & 5 & 0.2300 \\
\hline \multicolumn{8}{|l|}{ UNAM } \\
\hline Mean & 1.46 & 88.1 & 3967 & 8.3935 & 9.8 & 11.4 & 0.0941 \\
\hline $\mathrm{N}$ & 510 & 510 & 510 & 510 & 510 & 510 & 510 \\
\hline SD & 0.83 & 11.6 & 3385 & 0.7864 & 5.212 & 5 & 0.2900 \\
\hline
\end{tabular}




\begin{tabular}{lccccccc} 
Mean & 1.38 & 82.9 & 3896 & 8.5417 & 11.969 & 12.9 & 0.0833 \\
$\mathrm{~N}$ & 48 & 48 & 48 & 48 & 48 & 48 & 48 \\
$\mathrm{SD}$ & 0.96 & 15.8 & 3164 & 0.8124 & 3.676 & 4.2 & 0.2800 \\
TOTAL & & & & & & & \\
Mean & 2.33 & 67.9 & 2945 & 7.9248 & 8.6 & 10 & 0.0350 \\
$\mathrm{~N}$ & 3743 & 3743 & 3743 & 3743 & 3743 & 3743 & 3743 \\
$\mathrm{SD}$ & 2.03 & 18.5 & 2693 & 0.7982 & 5.1 & 5.2 & 0.1800 \\
\hline
\end{tabular}

1. This is the average preference number toward each institution from students who applied and got in.

2. Out of 128 questions.

3. In net pesos per month in 1999.

4. Grades go from 5 (fail) to 10.

5. Years of schooling.

Note: Colegio de Bachilleres is Federal; Estado de México is a state-centralized high school system; DGETI is the

Dirección General de Educación Técnica Profesional, a centralized institution; IPN is the Instituto Politécnico Nacional -centralized-; and UNAM is the Universidad Nacional Autónoma de México -autonomous-.

Table 10

Distribution of the 1994 Sample by Cohort

\begin{tabular}{ccccc}
\hline $\begin{array}{c}\text { Graduation Year } \\
\text { Cohort }\end{array}$ & Planned Selection & \% & Actual Selection & \% \\
\hline 1991 & 375 & 25 & 346 & 24.7 \\
1992 & 750 & 50 & 704 & 50.3 \\
1993 & 375 & 25 & 349 & 24.9 \\
Total & 1500 & 100 & 1399 & 100 \\
\hline
\end{tabular}

Source: CONALEP (1994).

Table 11

Actual Sample Selection (original and substitutes by cohort)

\begin{tabular}{ccccccc}
\hline & Selected & \multicolumn{3}{c}{ Substitutes } & Total & \% vs. 1,500 \\
\hline Graduation Year Cohort & $\mathrm{M}$ & $\mathrm{S}$ & $\mathrm{T}$ & $\mathrm{Z}$ & 346 & 23.1 \\
1991 & 268 & 53 & 20 & 5 & 704 & 49.9 \\
1992 & 560 & 96 & 42 & 6 & 349 & 23.3 \\
1993 & 286 & 46 & 15 & 2 & 1,399 & 93.3 \\
Total & 1,114 & 195 & 77 & 13 & & \\
Cumulative percentage & $74.3 \%$ & $87.3 \%$ & $92.4 \%$ & $93.3 \%$ & $93.3 \%$ & \\
\hline
\end{tabular}

Source: CONALEP (1994).

Table 12

Effective Interviews

\begin{tabular}{lcccccc}
\hline Category & & \multicolumn{5}{c}{ Cohort } \\
Number of interviews & $90-93$ & $91-94$ & $92-95$ & $93-96$ & $94-97$ & Total \\
Non-response & 795 & 817 & 783 & 738 & 750 & 3883 \\
Response & 781 & 952 & 1128 & 1268 & 1451 & 5580 \\
Planned Sample & 1576 & 1769 & 1911 & 2006 & 2201 & 9463 \\
$\begin{array}{l}\text { Percentage } \\
\text { Non-response }\end{array}$ & 50.4 & 46.2 & 41.0 & 36.8 & 34.1 & 41.0 \\
Response & 49.6 & 53.8 & 59.0 & 63.2 & 65.9 & 59.0
\end{tabular}


Planned Sample

100.0

100.0

100.0

100.0

100.0

100.0

Source: Own calculations based on CONALEP (1998).

Table 13

Reason for non-response

\begin{tabular}{lcccccc}
\hline & \multicolumn{5}{c}{ Cohort } \\
Category & $90-93$ & $91-94$ & $92-95$ & $93-96$ & $94-97$ & Total \\
\hline Dead & 0.5 & 0.4 & 0.0 & 0.3 & 0.0 & 0.2 \\
Works in another state/country & 4.4 & 4.7 & 3.2 & 4.7 & 4.8 & 4.4 \\
Temporary absence & 8.6 & 8.2 & 8.4 & 8.8 & 11.5 & 9.1 \\
Address was not found & 17.7 & 21.5 & 20.7 & 21.3 & 24.5 & 21.1 \\
Graduate is not know in that address & 14.5 & 13.6 & 11.2 & 9.9 & 11.2 & 12.1 \\
Graduate was not found (3rd visit) & 13.0 & 12.9 & 16.0 & 20.2 & 20.4 & 16.4 \\
Changed address and it is not known where to & 24.7 & 24.7 & 25.9 & 22.2 & 18.0 & 23.2 \\
Changed address and would not tell where & 2.9 & 2.6 & 2.7 & 3.4 & 1.5 & 2.6 \\
Changed address to another state & 0.4 & 0.0 & 0.1 & 0.0 & 0.0 & 0.1 \\
Changed address & 9.1 & 7.5 & 6.6 & 4.5 & 4.4 & 6.5 \\
Address insufficiently specified & 4.4 & 4.0 & 5.1 & 4.7 & 3.7 & 4.4 \\
Total & 100.0 & 100.0 & 100.0 & 100.0 & 100.0 & 100.0 \\
\hline Source: Own
\end{tabular}

Source: Own calculations based on CONALEP (1998)

Table 14

Graduate's gender

\begin{tabular}{|c|c|c|c|c|c|c|}
\hline Category & $90-93$ & $91-94$ & $\begin{array}{l}\text { Cohort } \\
92-95\end{array}$ & $93-96$ & $94-97$ & Total \\
\hline \multicolumn{7}{|c|}{ Non-respondents } \\
\hline Man & 68.7 & 69.3 & 70.2 & 69.4 & 69.2 & 69.4 \\
\hline Woman & 31.3 & 30.7 & 29.8 & 30.6 & 30.8 & 30.6 \\
\hline \multicolumn{7}{|c|}{ Respondents } \\
\hline Man & 68.1 & 63.4 & 67.8 & 66.5 & 68.0 & 66.8 \\
\hline Woman & 31.9 & 36.6 & 32.2 & 33.5 & 32.0 & 33.2 \\
\hline
\end{tabular}

Source: Own calculations

Table 15

Average Age

\begin{tabular}{lcccccc}
\hline Category & \multicolumn{5}{c}{ Cohort } \\
\hline Non-respondents & $90-93$ & $91-94$ & $92-95$ & $93-96$ & $94-97$ & Total \\
Respondents & 24.0 & 23.4 & 22.5 & 21.4 & 20.7 & 22.4 \\
Total & 24.0 & 23.2 & 22.1 & 21.5 & 20.0 & 21.9 \\
\hline
\end{tabular}

Source: Own calculations

\section{Figure 1}




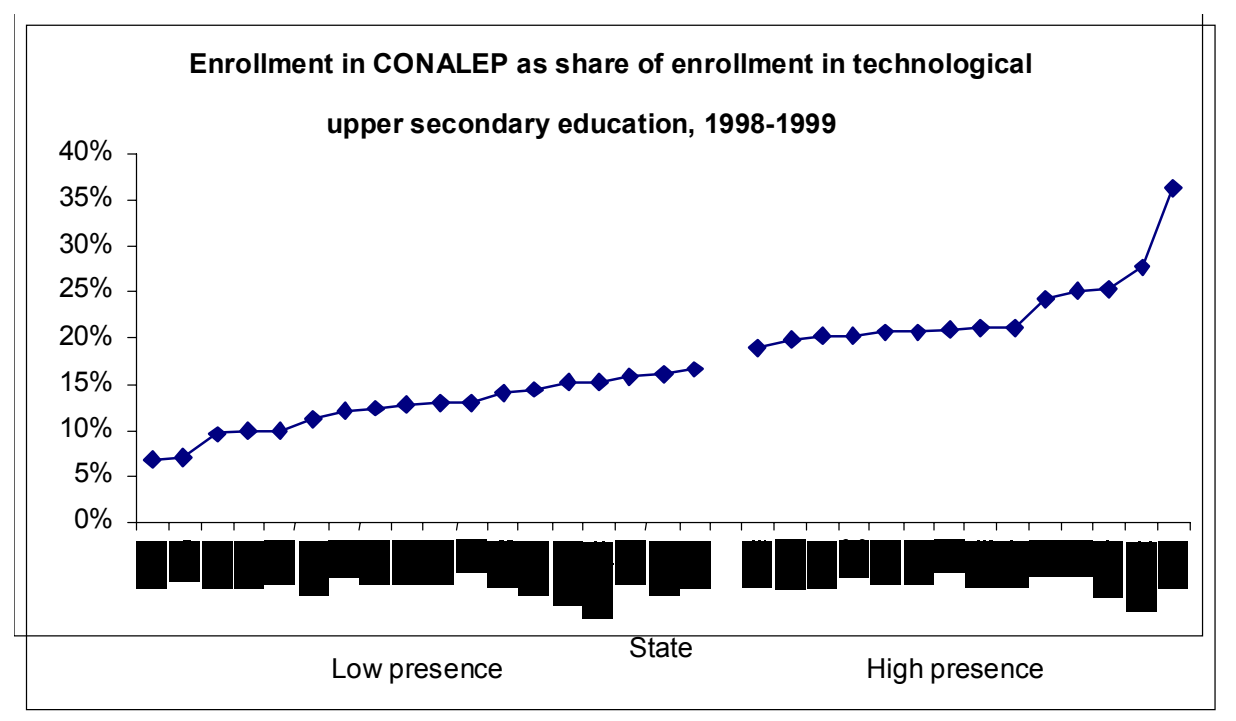

Table 16. Means of earnings per hour and share of people searching for a job by cohort and intensity of the program

\begin{tabular}{|c|c|c|c|c|c|c|}
\hline \multirow[b]{3}{*}{ Cohort } & \multicolumn{3}{|c|}{$\begin{array}{c}\text { Average earnings per hour (1999 current } \\
\text { pesos) }\end{array}$} & \multicolumn{3}{|c|}{ Searching for a job (\%) } \\
\hline & \multicolumn{2}{|c|}{ CONALEP's presence } & \multirow{2}{*}{ Difference } & \multicolumn{2}{|c|}{ CONALEP's presence } & \multirow{2}{*}{ Difference } \\
\hline & Low & High & & Low & High & \\
\hline \multicolumn{7}{|l|}{ Comparison of interest } \\
\hline 2) 18 to 23 years old in 1979 & 20.3 & 21.8 & $1.5(1.2)$ & 1.8 & 1.2 & $-0.6(0.9)$ \\
\hline 3) 4 to 9 years old in 1979 & 12.5 & 14.1 & $1.6(0.6)$ & 3.2 & 2.2 & $-1.1(0.9)$ \\
\hline Difference & $-7.7(1.0)$ & $-7.6(1.0)$ & $0.1(1.4)$ & $1.4(0.9)$ & $1.0(0.9)$ & $-0.5(1.3)$ \\
\hline \multicolumn{7}{|l|}{ Identification assumption test } \\
\hline 1) 24 to 29 years old in 1979 & 21.4 & 22.0 & $0.7(1.6)$ & 1.2 & 0.9 & $-0.3(1.0)$ \\
\hline 2) 18 to 23 years old in 1979 & 20.3 & 21.8 & $1.5(1.2)$ & 1.8 & 1.2 & $-0.6(0.9)$ \\
\hline Difference (std error) & $1.1(1.4)$ & $0.3(1.4)$ & $-0.9(2.0)$ & $-0.6(0.9)$ & $-0.3(0.9)$ & $0.3(1.3)$ \\
\hline
\end{tabular}

Only people with technical education after lower secondary were included in the analysis.

Standard errors are in parentheses. Significant differences at $90 \%$ confidence level are in bold.

Neither the ENE nor the ENECE distinguish between technical and technological tracks.

Source: Own calculations based on ENECE 99.

\section{Table 17. Estimated effects of CONALEP}

\begin{tabular}{cllll}
\hline Dependent variable & Effect & Std. Dev. & Statistic t & Probability \\
\hline Wages per hour & -0.0031 & 0.0052 & -0.61 & 0.54 \\
People searching job (percent) & -.0034 & 0.0028 & -1.47 & 0.142 \\
\hline
\end{tabular}

Source: Own calculations based on ENECE 99.

Table 18. Correctly predicted cases by the logit model (\%) excluding one of the variables

\begin{tabular}{lccc}
\hline Variable excluded in the model & No CONALEP & CONALEP & Overall \\
\hline None & 98.2 & 87.7 & 97.1 \\
Education & 97.7 & $\mathbf{2 0 . 4}$ & 90.0 \\
State of residence & 97.5 & 84.0 & 96.2 \\
Gender & 97.8 & 87.0 & 96.7
\end{tabular}


$\begin{array}{llll}\text { Age } & 97.0 & 74.1 & 94.7\end{array}$

$\begin{array}{llll}\text { Location where training } & 98.2 & 87.7 & 97.1\end{array}$

Source: Own calculations based on ENECE99 and CONALEP graduate tracer survey.

Table 19

Independent Variables Included in the Probit Model to find the Matching Group 3 nearest neighbors and probability scores

Using ENECE99

\begin{tabular}{|c|c|c|}
\hline & $\begin{array}{c}\text { Control Group } \\
n=782\end{array}$ & $\begin{array}{c}\text { CONALEP } \\
n=782\end{array}$ \\
\hline \multicolumn{3}{|l|}{ Education* } \\
\hline Technical complete with lower secondary & 78.7 & 76.5 \\
\hline Technical complete with upper secondary & 12.5 & 14.8 \\
\hline University incomplete & 6.3 & 6.6 \\
\hline University complete or more & 2.4 & 2.0 \\
\hline Total & 100.0 & 100.0 \\
\hline \multicolumn{3}{|l|}{ Gender* } \\
\hline Male & 52.6 & 52.9 \\
\hline Female & 47.4 & 47.1 \\
\hline Total & 100.0 & 100.0 \\
\hline \multicolumn{3}{|l|}{$A g e^{*}$} \\
\hline Mean & 24.4 & 24.2 \\
\hline Median & 24 & 23 \\
\hline Std. Deviation & 4.8 & 5.0 \\
\hline Minimum & 17 & 17 \\
\hline Maximum & 47 & 53 \\
\hline \multicolumn{3}{|l|}{ Percentiles } \\
\hline 20 & 20 & 21 \\
\hline 40 & 22 & 22 \\
\hline 60 & 25 & 24 \\
\hline 80 & 28 & 27 \\
\hline \multicolumn{3}{|l|}{ Training* } \\
\hline No training & 63.0 & 61.4 \\
\hline In-Firm Training & 25.1 & 25.2 \\
\hline External Training & 11.9 & 13.4 \\
\hline Total & 100.0 & 100.0 \\
\hline \multicolumn{3}{|l|}{ State } \\
\hline Aguascalientes & 3.7 & 1.5 \\
\hline Baja California & 0.1 & \\
\hline Baja California Sur & 3.3 & 1.5 \\
\hline Coahuila & 7.1 & 6.5 \\
\hline Chiapas & 2.9 & 3.2 \\
\hline Chihuahua & 1.7 & 2.7 \\
\hline Distrito Federal & 3.5 & 4.3 \\
\hline Guanajuato & 6.0 & 4.3 \\
\hline Guerrero & 1.2 & 0.6 \\
\hline Hidalgo & 2.1 & 7.9 \\
\hline
\end{tabular}




$\begin{array}{lcc}\text { Jalisco } & 6.0 & 12.3 \\ \text { México } & 11.7 & 11.8 \\ \text { Morelos } & 2.9 & 0.9 \\ \text { Nayarit } & 3.7 & 2.9 \\ \text { Nuevo León } & 5.9 & 3.7 \\ \text { Oaxaca } & 2.2 & 5.4 \\ \text { Puebla } & 3.9 & 6.9 \\ \text { Querétaro } & 2.8 & 2.4 \\ \text { Quintana Roo } & 1.9 & 3.6 \\ \text { SLP } & 3.0 & 5.9 \\ \text { Sinaloa } & 4.5 & 0.5 \\ \text { Sonora } & 5.0 & 4.0 \\ \text { Tabasco } & 2.3 & 2.7 \\ \text { Tamaulipas } & 7.8 & 1.4 \\ \text { Veracruz } & 4.8 & 2.9 \\ \text { Total } & 100.0 & 100.0\end{array}$

* There are not significant $(\mathrm{p}<0.1)$ differences between the means of the two groups.

Source: Own calculations. The reason why there are individuals with University complete and incomplete in the matching is because in the CONALEP graduate tracer survey there were people reporting having university incomplete (1 percent) and some other university complete ( 9 percent).

Table 20

Average Earnings, Earnings per Hour, and Hours Worked by Sample Group (1999 pesos) Matching group: Age 17-65. Three nearest neighbors based on propensity scores

\begin{tabular}{|c|c|c|c|c|c|c|c|c|c|c|}
\hline \multirow[b]{2}{*}{ Cohort } & \multirow[b]{2}{*}{ Cases } & \multicolumn{3}{|c|}{$\begin{array}{l}\text { Earnings } \\
\text { CONALE Differenc }\end{array}$} & \multicolumn{3}{|c|}{$\begin{array}{c}\text { Earnings per hour } \\
\text { CONALE }\end{array}$} & \multicolumn{3}{|c|}{$\begin{array}{c}\text { Hours worked per week } \\
\text { CONALE }\end{array}$} \\
\hline & & Ctrl Group & $P$ & $e$ & Ctrl Group & $P$ & Difference & Ctrl Group & $P$ & Difference \\
\hline $90-93$ & 143 & 2520.4 & 3397.2 & 876.8 & 13.6 & 18.1 & 4.5 & 44.2 & 45.3 & 1.1 \\
\hline $91-94$ & 166 & 2195.4 & 2569.6 & 374.2 & 12.2 & 14.7 & 2.5 & 44.4 & 46.0 & 1.6 \\
\hline $92-95$ & 133 & 2364.2 & 3253.7 & 889.5 & 13.1 & 19.5 & 6.4 & 43.9 & 44.7 & 0.8 \\
\hline $93-96$ & 119 & 2456.1 & 3023.0 & 566.9 & 13.6 & 16.1 & 2.5 & 43.7 & 46.8 & 3.0 \\
\hline $94-97$ & 94 & 2091.7 & 2045.6 & -46.1 & 11.4 & 13.0 & 1.6 & 45.4 & 45.8 & 0.3 \\
\hline Total $^{1 /}$ & 655 & 2333.1 & 2896.4 & 563.3 & 12.8 & 16.4 & 3.6 & 44.3 & 45.7 & 1.4 \\
\hline ENECE $99^{2 /}$ & & 2341.7 & & & 13.2 & & & 43.8 & & \\
\hline ENECE 99, LS $^{3 /}$ & & 1478.7 & & & 7.8 & & & 44.8 & & \\
\hline ENECE 99, US ${ }^{4 /}$ & & 2527.9 & & & 13.4 & & & 46.0 & & \\
\hline
\end{tabular}

1. Sample: Workers in the matching group.

2. Sample: All workers.

3. Sample: Workers with lower-secondary complete and 3 years of experience (18 and 19 years old).

4. Sample: Workers with upper-secondary complete and 1-5 years of experience (22-26 years old).

Significant differences at $90 \%$ confidence level are in bold

Note: ENECE99 control group.

Table 21

Working, searching for a job

Matching group: Age 17-65. Three nearest neighbors based on propensity scores

\begin{tabular}{l|l} 
Working people & Searching for a job
\end{tabular}

Cohort Ctrl Group CONALEP Difference Ctrl Group CONALEP Difference 


\begin{tabular}{lccc|ccc}
$90-93$ & 97.0 & 94.5 & -2.5 & 3.0 & 5.5 & 2.5 \\
$91-94$ & 95.7 & 93.1 & -2.7 & 4.3 & 6.9 & 2.7 \\
$92-95$ & 96.3 & 88.3 & $\mathbf{- 8 . 0}$ & 3.7 & 11.7 & 8.0 \\
$93-96$ & 94.7 & 88.8 & $\mathbf{- 5 . 9}$ & 5.3 & 11.2 & 5.9 \\
$94-97$ & 95.7 & 87.9 & $\mathbf{- 7 . 8}$ & 4.3 & 12.1 & 7.8 \\
Total $^{1 /}$ & 95.9 & 90.8 & $\mathbf{- 5 . 1}$ & 4.1 & 9.2 & 5.1 \\
& & & & & & \\
ECE 99 $^{2 /}$ & 98.1 & & & 1.9 & & \\
ECE 99, LS $^{3 /}$ & 95.7 & & & 4.3 & & \\
ECE 99, US $^{4 /}$ & 98.4 & & & 1.6 & &
\end{tabular}

1. Sample: Labor force in the matching group.

2. Sample: Labor force.

3. Sample: Labor force with lower-secondary complete and 3 years of experience (18 and 19 years old).

4. Sample: Labor force with upper-secondary complete and 1-5 years of experience (22-26 years old).

Significant differences at $90 \%$ confidence level are in bold

Note: ENECE99 control group.

Table 22

Employment Status by Sample Group

Matching group: Age 17-65. Three nearest neighbors based on propensity scores

\begin{tabular}{lccc} 
Category $^{I /}$ & Ctrl Group & CONALEP & Difference \\
\hline Employer & 1.7 & 3.3 & 1.7 \\
Self-employed & 8.4 & 10.5 & 2.1 \\
Employee & 84.6 & 83.8 & -0.7 \\
Cooperative membership & 0.1 & 0.6 & 0.5 \\
Worker without pay & 5.3 & 1.7 & -3.5
\end{tabular}

\begin{tabular}{lccc}
\hline Category & ${\text { ENECE } 99^{2 /}}^{2 /}$ & ${\text { ENECE 99, } \text { LS }^{3 /}}$ & ENECE 99, US $^{4 /}$ \\
\hline Employer & 4.0 & 0.2 & 2.9 \\
Self-employed & 24.4 & 4.4 & 9.2 \\
Employee & 60.8 & 79.6 & 81.4 \\
Cooperative membership & 0.03 & 0.00 & 0.02 \\
Worker without pay & 10.7 & 15.9 & 6.5 \\
\hline
\end{tabular}

1. Sample: Workers in the matching group.

2. Sample: All workers.

3. Sample: Workers with lower-secondary complete and 3 years of experience (18 and 19 years old).

4. Sample: Workers with upper-secondary complete and 1-5 years of experience (22-26 years old).

Significant differences at $90 \%$ confidence level are in bold

Note: ENECE99 control group.

Table 23

Activity Sector by Sample Group

Matching group: Age 17-65. Three nearest neighbors based on propensity scores

\begin{tabular}{lccc}
\hline Category $^{l /}$ & Ctrl Group & CONALEP & Difference \\
\hline Agriculture, fishing, etc. & 2.1 & 0.6 & -1.5 \\
Extraction & 0.1 & 0.4 & 0.3 \\
Manufacturing & 23.5 & 32.1 & $\mathbf{8 . 6}$ \\
Construction & 3.5 & 1.8 & -1.7 \\
Electricity, gas and water & 0.6 & 0.9 & 0.3
\end{tabular}




\begin{tabular}{lccc} 
Commerce, Restaurants and Hotels & 27.5 & 23.6 & -3.9 \\
Transportation and Communications & 5.3 & 3.1 & -2.2 \\
Financial Services. & 1.7 & 2.9 & 1.2 \\
Personal, Common, and Social Servs. & 35.6 & 34.6 & -1.0 \\
\hline Category & ENECE $99^{2 /}$ ENECE 99, LS $^{3 /}$ ENECE 99, US ${ }^{4 /}$ \\
Agriculture, fishing, etc. & 21.0 & 17.2 & 4.1 \\
Extraction & 0.3 & 0.1 & 0.2 \\
Manufacturing & 18.8 & 30.5 & 18.2 \\
Construction & 5.53 & 4.71 & 2.29 \\
Electricity, gas and water & 0.5 & 0.1 & 0.3 \\
Commerce, Restaurants and Hotels & 21.5 & 22.1 & 32.8 \\
Transportation and Communications & 4.5 & 2.1 & 8.8 \\
Financial Services. & 0.9 & 0.2 & 2.9 \\
Personal, Common, and Social Servs. & 27.0 & 22.9 & 30.5 \\
\hline
\end{tabular}

1. Sample: Workers in the matching group.

2. Sample: All workers.

3. Sample: Workers with lower-secondary complete and 3 years of experience (18 and 19 years old). 4. Sample: Workers with upper-secondary complete and 1-5 years of experience (22-26 years old). Significant differences at $90 \%$ confidence level are in bold Note: ENECE99 control group.

Table 24

Training is related to work by Sample Group Matching group: Age 17-65. Three nearest neighbors based on propensity scores

\begin{tabular}{|c|c|c|c|c|c|c|}
\hline Cohort & Ctrl Group & $\begin{array}{c}\text { Yes } \\
\text { CONALEP }\end{array}$ & Difference & Ctrl Group & $\begin{array}{c}\text { No } \\
\text { CONALEP } \\
\end{array}$ & Difference \\
\hline $90-93$ & 90.9 & 95.7 & 4.7 & 9.1 & 4.3 & -4.7 \\
\hline $91-94$ & 84.2 & 88.3 & 4.1 & 15.8 & 11.7 & -4.1 \\
\hline $92-95$ & 85.5 & 85.5 & 0.0 & 14.5 & 14.5 & 0.0 \\
\hline $93-96$ & 87.3 & 88.2 & 1.0 & 12.7 & 11.8 & -1.0 \\
\hline $94-97$ & 81.4 & 90.0 & 8.6 & 18.6 & 10.0 & -8.6 \\
\hline Total $^{1 /}$ & 86.1 & 89.7 & 3.6 & 13.9 & 10.3 & -3.6 \\
\hline ENECE $99^{2 /}$ & 86.1 & & & 13.9 & & \\
\hline ENECE 99, LS $^{3 /}$ & 74.2 & & & 25.8 & & \\
\hline ENECE $99, \mathrm{US}^{4 /}$ & 77.7 & & & 22.3 & & \\
\hline
\end{tabular}

1. Sample: Workers in the matching group.

2. Sample: All workers.

3. Sample: Workers with lower-secondary complete and 3 years of experience (18 and 19 years old). 4. Sample: Workers with upper-secondary complete and 1-5 years of experience (22-26 years old). Significant differences at $90 \%$ confidence level are in bold Note: ENECE99 control group. 